\title{
Pengaruh fish bowl technique terhadap kemampuan menganalisis teks negosiasi siswa kelas X SMA Negeri I Tanjungbalai
}

\section{Meilina Suryani Sagala ${ }^{\mathrm{I}}$, Trisnawati Hutagalung ${ }^{2}$}

Pendidikan Bahasa dan Sastra Indonesia, Fakultas Bahasa dan Seni, Universitas Negeri Medan, Jl. Rumah Sakit H., Kenangan Baru, Kecamatan Percut Sei Tuan, Medan, Indonesia

I meilinasagala30@gmail.com ", ${ }^{2}$ trisnawati.hutagalung@yahoo.co.id

* Corresponding author: meilinasagala30@gmai.com

\begin{tabular}{l}
\hline Sejarah Artikel Diterima: I0 September 2020 Direvisi: 25 Oktober 2020 Tersedia Daring: 3I Oktober 2020 \\
ABSTRAK \\
\hline \hline Fish bowl merupakan proses menyediakan cara kreatif untuk memasukkan publik dalam sebuah diskusi kelompok kecil. \\
Teknik ini dapat membantu membawa transparansi dalam proses pengambilan keputusan dan meningkatkan kepercayaan \\
dan pemahaman. Penelitian ini bertujuan untuk menggambarkan pengaruh fish bowl technique terhadap kemampuan \\
menganalisis teks negosiasi. Populasi penelitian ini adalah seluruh siswa Kelas X SMA Negeri I Tanjungbalai tahun \\
pembelajaran 20I9/2020 terdiri dari 8 kelas dengan jumlah siswa 282 orang. Teknik pengambilan sampel pada penelitian \\
ini menggunakan teknik purposive sampling. Sampel yang diambil adalah kelas X IS- I berjumlah 35 siswa. Metode dalam \\
penelitian ini adalah metode eksperimen dengan desain one group pre-test post-test. Nilai rata-rata pree-test siswa yaitu \\
sebeleum menerapkan fish bowl technique sebesar 6I,79, dengan kategori cukup belum memenuhi KKM, dan nilai rata-rata \\
post-test siswa yaitu sesudah menerapkan fish bowl technique sebesar 81,72 , dengan kategori baik sudah memenuhi KKM. \\
Berdasarkan hasil analisis, diperoleh bahwa data berdistribusi normal. Setelah dilakukan perhitungan, perhitungan thitung $>$ \\
trabel yaitu 5,I9>2,032, sehingga hipotesis nihil (Ho) ditolak dan hipotesis alternatif (Ha) diterima. Jadi dapat disimpulkan \\
bahwa fish bowl technique berpengaruh positif terhadap kemampuan menganalisis teks negosiasi siswa kelas X SMA Negeri \\
I Tanjungbalai. Oleh karena itu, penerapan fish bowl technique direkomendasikan untuk menjadi salah satu referensi model \\
pembelajaran yang dapat digunakan guru untuk menciptakan variasi pembelajaran dan meningkatkan kemampuan serta hasil \\
belajar siswa.
\end{tabular}

Kata Kunci Fish bowl technique, Kemampuan menganalisis, Teks negosiasi

\section{ABSTRACT}

The fish bowl is a process of providing a creative way to include the public in a small group discussion. These techniques can help bring transparency to the decision-making process and increase trust and understanding. This study aims to describe the effect of the Fish Bowl Technique on the Ability to Analyze Negotiation Text. This study's population were all students of Class X SMA Negeri I Tanjungbalai in the 2019/2020 learning year consisting of 8 classes with 282 students. The sampling technique in this study was the purposive sampling technique. The sample taken is class X IS-I totaling 35 students. The method in this research is an experimental method with one group pre-test post-test design. Before applying the fish bowl technique, the average pre-test score was 6I.79, with the sufficient category not meeting the KKM, and the post-test average score of students after applying the fish bowl technique was 81.72 with the good category already fulfill the KKM. Based on the results of the analysis, it was found that the data were normally distributed. After the calculation is done, the calculation of tcount $>$ ttable is 5.19> 2.032, so that the null hypothesis (Ho) is rejected and the alternative hypothesis $(\mathrm{Ha})$ is accepted. So it can be concluded that the fishbowl technique has a positive effect on the ability to analyze negotiation text for class X SMA Negeri I Tanjungbalai. Therefore, the application of the fishbowl technique is recommended to be a reference for learning models that teachers can use to create learning variations and improve student learning abilities and outcomes.

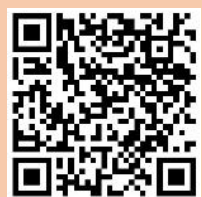

Copyright@2020, Meilina Suryani S, Trisnawati Hutagalung This is an open access article under the CC-BY-3.0 license

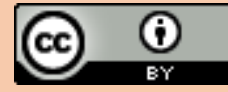

\begin{tabular}{|c|c|}
\hline Keywords & Fish bowl technique, Analyze abilities, Text negotiations \\
\hline Cite & $\begin{array}{l}\text { Sagala, M. S., \& Hutagalung, T. (2020). Pengaruh fish bowl technique terhadap kemampuan } \\
\text { menganalisis teks negosiasi siswa kelas X SMA Negeri I Tanjungbalai. KEMBARA: Jurnal Keilmuan }\end{array}$ \\
\hline & 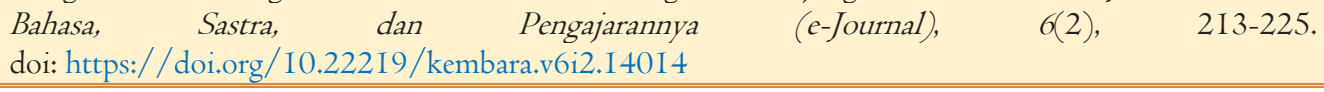 \\
\hline
\end{tabular}




\section{PENDAHULUAN}

Pendidikan merupakan usaha sadar yang dilakukukan oleh keluarga, masyarakat dan pemerintah melalui kegiatan bimbingan, pengajaran, dan latihan yang berlangsung di sekolah maupun luar sekolah (Sagala, 20I4). Pada Kurikulum 2013 ditegaskan bahwa pembelajaran bahasa Indonesia saat ini merupakan pembelajaran berbasis teks, dengan harapan dapat memberi kesempatan kepada siswa untuk mengembangkan berbagai jenis struktur berpikir yang berbeda satu sama lain. Salah satu jenis teks yang harus dikuasai itu adalah teks negosiasi. Mahsun (2014) menyebutkan, semakin banyak jenis teks yang dikuasai, maka semakin banyak struktur berpikir yang dikuasai siswa. Isodarus (2017) mengatakan teks atau wacana adalah satuan kebahasaan terbesar atau terlengkap, yang mencakup teks lisan dan teks tertulis. Pembelajaran menganalisis teks negosiasi terdapat pada kompetensi dasar 3.I I menganalisis isi struktur, dan kebahasaan teks negosiasi. Kemendikbud (20I4) menjelaskan bahwa salah satu kompetensi yang harus dikuasai oleh siswa adalah menganalisis teks negosiasi. Kompetensi dasar yang ditetapkan oleh penulis pada penelitian ini berdasarkan kurikulum 2013 adalah kompetensi dasar pada mata pelajaran bahasa Indonesia untuk siswa SMA kelas X semester 2. Dalam hal ini, siswa dituntut untuk mampu menganalisis teks negosiasi yang sesuai dengan isi, struktur, dan kaidah kebahasaan.

Menurut Alwi (2007) menganalisis teks yang dimaksudkan agar siswa bisa menilai dan mengevaluasi bagian ataupun struktur teks negosiasi. Sementara itu, menganalisis berarti melakukan analisis. Istiningsih, Widari, \& Hasanah, (2018) berpendapat baha analisis adalah serangkaian perbuatan meneliti, mengurai, membedakan, memilah sesuatu untuk digolongkan serta dikelompokkan berdasarkan keterikatan serta penafsiran makna dari setiap kriteria. Kosasih (20I4) berpendapat bahwa teks negosiasi dapat diartikan sebagai upaya untuk mencapai suatu kesepakatan melalui suatu bentuk diskusi ataupun percakapan. Teks negosiasi memiliki struktur secara garis besar yaitu pembuka, isi dan penutup, sedangkan struktur teks negosiasi secara terperinci yaitu orientasi, permintaan, pemenuhan, penawaran, persetujuan, pembelian, dan penutup (Dewi, Suandi, \& Yasa, 2015; Huda, Turahmat, \& Azizah, 2018; Fristanti, Sudarmaji, \& Saputro, 2019). Kata negosiasi diambil dari bahasa latin negotiari yang berarti 'berdagang atau berbisnis'. Kata kerja yang diambil dari kata lain ialah negare yang berarti 'meniadakan' dan satu kata benda otium berarti 'waktu luang' hingga kesepakatan tercapai (Wahidin, 2015).

Berdasarkan observasi dan peninjauan lapangan pemahaman tentang menganalisis sebuah teks terutama teks negosiasi di kalangan para siswa merupakan masalah yang cukup rumit, siswa masih kurang memahami tentang proses menganalisis, sehingga siswa merasa kesulitan dalam menganalisis teks negosiai. Dikatakan demikian, karena kemampuan siswa dalam menganalisis sebuah teks masih rendah. Berdasarkan hasil wawancara peneliti pada hari Rabu I8 Desember 2019 dengan salah satu guru bidang studi bahasa Indonesia yang ada di SMA Negeri I Tanjungbalai ibu Prama Nita Marpaung, S.Pd, menjelaskan bahwa siswa masih kesulitan dalam menganalisis teks negosiasi yang masih tergolong kurang dengan nilai ratarata 55,5. Nilai KKM pada standar kompetensi di sekolah tersebut adalah 75 siswa belum mencapai kriteria ketuntasan minimum (KKM). Banyak faktor yang menyebabkan hal itu terjadi, salah satunya adalah pemilihan teknik yang tidak tepat, siswa cenderung merasa bosan dengan pembelajaran yang kurang bervariasi dalam menganalisis teks negosiasi (Zumaeroh, 20I0). Hal ini dibuktikan dengan penelitian yang dilakukan oleh (Eviyana, Hilal, \& Karomani (2013); Ulina, 2016; Sunarsih, Adelina, \& Yanti, 2018; Sartika, 2019) menjelaskan bahwa siswa belum sepenuhnya menguasai kegiatan menganalisis teks. Siswa masih kesulitan tentang bagaimana sebenarnya kegiatan menganalisis dan apa yang harus dianalisis dari sebuah teks, sehingga menyebabkan nilai 75 untuk kriteria ketuntasan minimum (KKM) tidak tercapai. Permasalahan lain yang juga menunjukkan permasalahan yang sama dapat dibuktikan dari penelitian Francisko (2015); Patonah, Syahrullah, Firmansyah, \& Fauziya, 2018; Silvia, 2019; Palupi, 2020) didapatkan nilai rata-rata yang masih tergolong kategori cukup baik dengan nilai 62,7I. Nilai tersebut didapatkan siswa sebelum diberikan teknik pembelajaran yang tepat untuk menganalisis teks. Berdasarkan 
penjelasan di atas, maka dapat dipahami bahwa hasil belajar siswa dalam menganalisis teks negosiasi tergolong rendah.

Roestiyah (2008) menyatakan di dalam proses belajar mengajar, guru harus memiliki strategi, agar siswa dapat belajar secara aktif, dan efektif, sehingga tujuan yang diharapkan dapat tercapai. Salah satu langkah untuk memiliki strategi pembelajaran itu ialah harus menguasai teknik-teknik penyajian, atau biasanya disebut teknik pembelajaran (Zaini, 2010). Guru sebagai penyampai materi kepada siswa harus dapat menyampaikan materi yang dibahas dengan teknik, metode serta strategi yang tepat dan menarik. Namun, masih ada guru yang menyampiakan materi secara monoton (ceramah). Hal ini mengakibatkan siswa kurang aktif dalam kegiatan belajar mengajar. Kemampuan memilih teknik pembelajaran yang akan digunakan oleh guru dalam proses pembelajaran sangat berpengaruh besar terhadap pencapaian tujuan pendidikan dan pembelajaran. Menurut Warsono dan Hariyanto (2013) menjelaskan ada bermacam teknik untuk mendapatkan keaktifan dalam belajar, salah satunya adalah dengan menggunakan teknik mangkuk ikan atau akuarium (fish bowl) yang dirasa peneliti dapat membantu meningkatkan hasil belajar siswa. Melalui pemanfaatan teknik pembelajaran yang menarik dan bervariasi tentu akan memudahkan siswa dalam belajar sekaligus dapat membuat suasana belajar menjadi lebih interaktif sehingga berdampak positif bagi hasil kemampuan siswa dalam menganalisis teks negosiasi. Untuk mengatasi masalah tersebut penyusun memberikan solusi dalam penggunaan teknik pembelajaran fish bowl technique yang diharapkan dapat meningkatkan pemahaman siswa mengenai menganalisis teks negosiasi berdasarkan isi, struktur, dan kaidah kebahasaan (Aswadi \& Akhmad, 20I6; Effendi, 2018).

Fish bowl technique merupakan proses menyediakan cara kreatif untuk memasukkan publik dalam sebuah diskusi kelompok kecil. Teknik ini dapat membantu membawa transparansi dalam proses pengambilan keputusan dan meningkatkan kepercayaan dan pemahaman (Tricio, Montt, Orsini, Gracia, Pampin, Quinteros, \& Fuentes, 2019). Dalam diskusi ini terdiri dari seorang moderator dan satu atau tiga manusia sumber pendapat, mereka duduk menghadap kelompok besar. Kemudian moderator memberikan pengantar singkat, diikuti dengan meminta kepada peserta diskusi dengan sukarela dari kelompok besar untuk mengajukan pertanyaan atau mengadakan pembicaraan dengan manusia sumber pendapat. Selanjutnya moderator mengundang peserta yang lainnya dari anggota sidang untuk ikut berpartisipasi (Roestiyah, 2012).

Pembelajaran dengan menggunakan fish bowl technique merupakan suatu pembelajaran yang dapat digunakan untuk mengembangkan situasi belajar melalui diskusi, terbuka, dan membutuhkan pendapat yang berbeda-beda pembelajaran menggunakan fish bowl technique ini dilakukan secara berdiskusi dimana siswa akan dibagi menjadi dua kelompok yaitu kelompok lingkaran dalam dan kelompok lingkaran luar. Kelompok lingkaran dalam bertugas untuk mendiskusikan masalah atau materi yang akan dipelajari, sedangkan kelompok luar bertugas untuk menyaksikan diskusi serta memberikan tanggapan.

Beberapa penelitian menunjukkan bahwa teknik pembelajaran fish bowl technique memengaruhi proses pembelajaran, salah satu contoh penelitian yang dilakukan (Rahmadani, 20I4) nilai rata-rata kelas eksperimen adalah 78,06 sedangkan untuk kelas kontrol adalah 65. Dengan demikian, dapat dikatakan bahwa nilai rata-rata kemampuan menulis pada kelas eksperimen lebih tinggi daripada kelas kontrol. Ini terbukti dari hasil uji " $\mathrm{t}$ " diperoleh thitung $>$ tabel yaitu 7,86 > 2,03. Penelitian lain yang dilakukan oleh (Fitri dan Niniwati, 20I5) didapat rata-rata hasil belajar kelas eksperimen lebih baik dari pada hasil belajar kelas kontrol, dengan demikian dapat disimpulkan bahwa hasil belajar matematika siswa yang diajar menggunakan pembelajaran teknik cawan ikan lebih baik dari hasil belajar matematika siswa yang pembelajarannya menggunakan pembelajaran konvensional.

Berdasarkan hasil uraian penjelasan di atas dapat disimpulkan dari penyaringan data hasil pencarian dari tahun-tahun yang paling terendah. Penelitian ini menjukkan adanya pengaruh signifikan dalam penggunaan fish bowl technique terhadap proses pembelajaran. Penelitian lain yang menujukkan bahwa fish bowl efektif dalam model pembelajaran Athirah, Garancang, Suhardiman (2018) pada proses pembelajaran dengan menggunakan teknik fish bowl technique memiliki salah satu kelebihan yakni dapat 
meningkatkan pemahaman konsep karena pada teori Gagne dalam pembelajaran terjadi proses penerimaan informasi yang kemudian diolah, sehingga menghasilkan luaran dalam bentuk hasil. Hasil pembelajaran merupakan terdiri atas informasi verbal, kecakapan intelektual, strategi kognitif, sikap dan kecakapan motorik. Pemahaman konsep pada siswa yang menggunakan fish bowl technique lebih efektif karena setiap siswa (individu atau kelompok) diberikan kesempatan yang sama untuk mempertangungjawabkan secara mandiri untuk menjelaskan materi kepada teman yang lainnya. Penelitian terakhir yang juga menjukkan bahwa fish bowl efektif dalam proses pembelajaran yaitu penelitian yang dilakukan oleh Istiningsih, Widari, \& Hasanah, (2018) pada siklus I diperoleh nilai rata-rata 75,375 dengan ketuntasan klasikal 70,83\% dan skor rata-rata aktivitas siswa 53 dengan kategori cukup aktif. Pada siklus II data hasil belajar dan aktivitas siswa mengalami peningkatan yakni rata-rata 82,79I dengan ketuntasan klasikal $87,5 \%$ dan skor rata-rata aktivitas belajar siswa 58,5 dengan kriteria aktif.

Berdasarkan uraian di atas peneliti bermaksud melakukan penelitian dengan judul pengaruh fish bowl technique terhadap kemampuan menganalisis teks negosiasi siswa kelas X SMA Negeri I Tanjungbalai tahun pembelajaran 2019/2020. Dengan adanya penerapan teknik pembelajaran ini diharapkan akan dapat meningkatkan keaktifan, motivasi, dan hasil belajar siswa. Berdasarkan latar belakang, maka perlu kiranya dilakukan penelitian permasalahan yang akan diteliti dalam penelitian ini, yaitu: (I) bagaimanakah kemampuan siswa kelas X SMA Negeri I Tanjungbalai tahun pembelajaran 2019/2020 dalam menganalisis teks negosiasi sebelum menggunakan fish bowl technique? (2) bagaimanakah kemampuan siswa kelas X SMA Negeri I Tanjungbalai tahun pembelajaran 2019/2020 dalam menganalisis teks negosiasi setelah menggunakan fish bowl technique? (3) bagaimanakah pengaruh penggunaan teknik pembelajaran fish bowl technique terhadap kemampuan siswa kelas X SMA Negeri I Tanjungbalai tahun pembelajaran 2019/2020 dalam menganalisis teks negosiasi?

Tujuan dilakukannya penelitian ini adalah sebagai berikut: (I) untuk menganalisis kemampuan siswa kelas X SMA Negeri I Tanjungbalai tahun pembelajaran 2019/2020 dalam menganalisis teks negosiasi sebelum menggunakan fish bowl technique; (2) untuk menganalisis kemampuan siswa kelas X SMA Negeri I Tanjungbalai tahun pembelajaran 2019/2020 dalam menganalisis teks negosiasi sesudah menggunakan fish bowl technique; (3) untuk menganalisis adakah pengaruh fish bowl technique terhadap kemampuan siswa kelas X SMA Negeri I Tanjungbalai tahun pembelajaran 2019/2020 dalam menganalisis teks negosiasi. Hasil dari penelitian ini juga dapat digunakan guru sebagai salah satu referensi yang dapat diterapkan baik dalam materi pembelajaran menganalisis teks negosiasi maupun materi pembelajaran bahasa Indonesia lainnya.

\section{METODE}

Penelitian ini dilakukan di SMA Negeri I Tanjungbalai pada siswa kelas X tahun pembelajaran 2019/2020. Populasi dalam penelitian ini adalah seluruh siswa kelas X di SMA Negeri I Tanjungbalai tahun pembelajaran 2019/2020 dengan jumlah sebanyak 282 siswa. Dalam proses pengambilan sampel digunakan teknik purposive sampling, yaitu apabila sasaran sampel yang diteliti telah memiliki karakteristik tertentu, sehingga tidak mungkin diambil sampel lain yang tidak memenuhi karakteristik yang telah ditetapkan. Karakteristik sampel yang diambil sudah ditetapkan oleh peneliti sehingga teknik purposive sampling ini dinamakan sampel bertujuan yaitu siswa yang paling banyak mendapat nilai dibawah KKM adalah siswa yang akan menjadi sumber data dalam penelitian ini. Berdasarkan karakteristik tersebut dari seluruh siswa kelas X yang ada di SMA Negeri I Tanjungbalai, kelas yang paling banyak mendapat kan nilai dibawah KKM yaitu kelas X IS-I maka sampel yang ditetapkan dalam penelitian ini adalah kelas XIS-I yang berjumlah 35 siswa. Metode penelitian yang digunakan dalam penelitian ini adalah metode kuantitatif dengan bentuk eksperimen dan penelitian deskriptif dengan tipe tes awal-tes akhir kelompok tunggal (the one group pre-test-post-test). Sugiyono (2016) menjelaskan bahwa penelitian kuantitatif sebagai suatu proses untuk menemukan pengetahuan dengan menggunakan data berupa angka untuk menentukan keterangan tentang sesuatu yang kita cari. Penelitian ini menggunakan dua jenis variabel, yaitu variabel bebas; teknik pembelajaran fish bowl technique dan yang menjadi variabel terikat adalah menganalisis teks negosiasi. 
Desain penelitian ini adalah one group pre-test dan post-test design. Di dalam desain penelitian penelitian ini penilaian dilakukan sebanyak dua kali yaitu sebelum eksperimen dan sesudah eksperimen. Penilaian yang dilakukan sebelum eksperimen disebut pre-test, dan sesudah observasi disebut post-test. Desain dengan model ini, memberi perlakuan yang sama pada setiap subjek tanpa memperhitungkan dasar kemampuan yang dimiliki. Kesimpulan, siswa yang menjadi sampel dalam penelitian ini akan mendapatkan hak yang sama yaitu tes awal tanpa menggunakan fish bowl technique. Kemudian tes akhir setelah menggunakan fish bowl technique. Untuk menunjang data dalam penelitian ini digunakan dua instrumen penelitian, yaitu observasi dan tes. Observasi dilakukan untuk mengumpulkan data mengenai kemampuan awal siswa menganalisis teks negosiasi, sedangkan tes digunakan untuk mengumpulkan data mengenai kemampuan menganalisis teks negosiasi setelah mendapat perlakuan. Tabel I merupakan instrumen penilaian menulis menganalisis teks negosiasi:

Tabel I

Instrumen Penilaian Menganalisis Teks Negosiasi

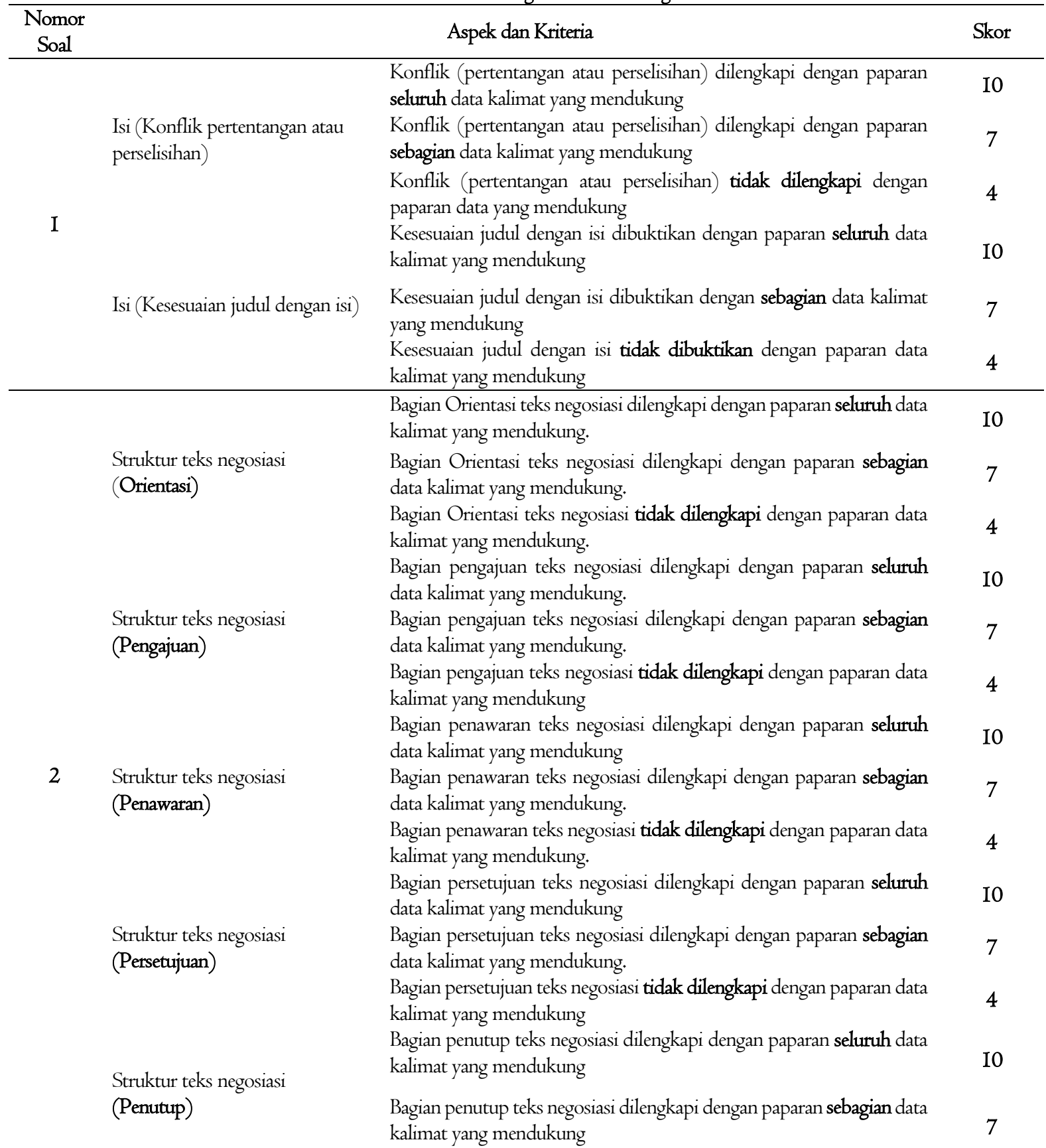




\begin{tabular}{|c|c|c|c|}
\hline & & $\begin{array}{l}\text { Bagian penutup teks negosiasi tidak dilengkapi dengan paparan data } \\
\text { kalimat yang mendukung }\end{array}$ & 4 \\
\hline \multirow[t]{18}{*}{3.} & \multirow{3}{*}{$\begin{array}{l}\text { Kaidah kebahasaan dan data } \\
\text { (kalimat berita) }\end{array}$} & $\begin{array}{l}\text { Penggunaan kalimat berita dilengkapi dengan paparan seluruh data } \\
\text { kalimat yang mendukung }\end{array}$ & I0 \\
\hline & & $\begin{array}{l}\text { Penggunaan kalimat berita. dilengkapi dengan paparan sebagian data } \\
\text { kalimat yang mendukung }\end{array}$ & 7 \\
\hline & & $\begin{array}{l}\text { Penggunaan kalimat berita tidak dilengkapi dengan paparan data } \\
\text { kalimat yang mendukung }\end{array}$ & 4 \\
\hline & \multirow{3}{*}{$\begin{array}{l}\text { Kaidah kebahasaan dan data } \\
\text { (kalimat tanya) }\end{array}$} & $\begin{array}{l}\text { Penggunaan kalimat tanya dilengkapi dengan paparan seluruh data } \\
\text { kalimat yang mendukung }\end{array}$ & I0 \\
\hline & & $\begin{array}{l}\text { Penggunaan kalimat tanya dilengkapi dengan paparan sebagian data } \\
\text { kalimat yang mendukung }\end{array}$ & 7 \\
\hline & & $\begin{array}{l}\text { Penggunaan kalimat tanya tidak dilengkapi dengan paparan data } \\
\text { kalimat yang mendukung. }\end{array}$ & 4 \\
\hline & \multirow{3}{*}{$\begin{array}{l}\text { Kaidah kebahasaan dan data } \\
\text { (kalimat perintah) }\end{array}$} & $\begin{array}{l}\text { Penggunaan kalimat perintah dilengkapi dengan paparan seluruh data } \\
\text { kalimat yang mendukung }\end{array}$ & I0 \\
\hline & & $\begin{array}{l}\text { Penggunaan kalimat perintah dilengkapi dengan paparan sebagian data } \\
\text { kalimat yang mendukung }\end{array}$ & 7 \\
\hline & & $\begin{array}{l}\text { Penggunaan kalimat perintah tidak dilengkapi dengan paparan data } \\
\text { kalimat yang mendukung. }\end{array}$ & 4 \\
\hline & \multirow{3}{*}{$\begin{array}{l}\text { Kaidah kebahasaan dan data } \\
\text { (kalimat yang menyatakan } \\
\text { keinginan atau harapan ) }\end{array}$} & $\begin{array}{l}\text { Penggunaan kalimat yang menyatakan keinginan atau harapan } \\
\text { dilengkapi dengan paparan seluruh data kalimat yang mendukung }\end{array}$ & I0 \\
\hline & & $\begin{array}{l}\text { Penggunaan kalimat yang menyatakan keinginan atau harapan } \\
\text { dilengkapi dengan paparan sebagian data kalimat yang mendukung }\end{array}$ & 7 \\
\hline & & $\begin{array}{l}\text { Penggunaan kalimat yang menyatakan keinginan atau harapan tidak } \\
\text { dilengkapi dengan paparan data kalimat yang mendukung. }\end{array}$ & 4 \\
\hline & \multirow{3}{*}{$\begin{array}{l}\text { Kaidah kebahasaan dan data } \\
\text { (kalimat bersyarat) }\end{array}$} & $\begin{array}{l}\text { Penggunaan kalimat bersyarat dilengkapi dengan paparan seluruh data } \\
\text { kalimat yang mendukung }\end{array}$ & I0 \\
\hline & & $\begin{array}{l}\text { Penggunaan kalimat bersyarat dilengkapi dengan paparan sebagian } \\
\text { data kalimat yang mendukung }\end{array}$ & 7 \\
\hline & & $\begin{array}{l}\text { Penggunaan kalimat bersyarat tidak dilengkapi dengan paparan data } \\
\text { kalimat yang mendukung. }\end{array}$ & 4 \\
\hline & \multirow{3}{*}{$\begin{array}{l}\text { Kaidah Kebahasaan dan data } \\
\text { (Konjungsi) }\end{array}$} & $\begin{array}{l}\text { Adanya konjungsi penyebab (kausalitas dilengkapi dengan paparan } \\
\text { seluruh data kalimat yang mendukung }\end{array}$ & I0 \\
\hline & & $\begin{array}{l}\text { Adanya konjungsi penyebab (kausalitas) dilengkapi dengan paparan } \\
\text { sebagian data kalimat yang mendukung }\end{array}$ & 7 \\
\hline & & $\begin{array}{l}\text { Adanya konjungsi penyebab (kausalitas) tidak dilengkapi dengan } \\
\text { paparan data kalimat yang mendukung. }\end{array}$ & 4 \\
\hline
\end{tabular}

Untuk mendapatkan nilai dari skor tersebut dilakukan dengan cara sebagai berikut.

$$
\text { Nilai Akhir }=\frac{\text { Skor yang diperoleh }}{\text { Skor maksimal }} \times 100
$$

Teknik analisis data yang digunakan dalam menganilisis data penelitian ini adalah teknik uji-t (t-test). Tujuannya untuk mengetahui apakah data perbedaan antara kedua nilai tersebut secara signifikan, maka digunakan rumus uji-t (t- test). Beberapa langkah yang dilakukan untuk memperoleh data adalah: (I) tabulasi skor pre-test skor post-test, (2) mencari mean variable hasil pre-test dan post-test, (3) mencari standar deviasi hasil pre-test dan post-test, (3) mencari standar eror mean hasil pre-test dan post-test, (4) mencari standar eror perbedaan mean kedua hasil. (5) melakukan uji hipotesis dengan menggunakan uji " $\mathrm{t}$ ".

\section{HASIL DAN PEMBAHASAN}

Penelitian ini berjenis penelitian eksperimen dengan desain penelitian one group pre-test dan posttest design yang bertujuan untuk mengetahui adakah pengaruh fish bowl technique terhadap kemampuan menganalisis teks negosiasi siswa kelas X SMA Negeri I Tanjunbalai. Penelitian ini bertujuan untuk 
mendiskripsikan pengaruh fish bowl technique terhadap kemampuan menganalisis teks negosiasi siswa. Kegiatan penelitian ini dilaksanakan selama semester genap tahun pembelajaran 2019/2020.

\section{Kemampuan Menganalisis Teks Negosiasi sebelum Menerapkan Fish Bowl Technique (Pre-Test)}

Berdasarkan nilai hasil belajar dalam menganalisis teks negosias sebelum menggunakan fish bowl technique diperoleh penyebaran nilai sebesar 43,7 sampai dengan 93. Maka, nilai tertinggi yang diperoleh siswa sebesar 93 dan nilai terendah yang diperoleh adalah 43,7.

Selanjutnya, dilakukan perhitungan analisis data, diperoleh nilai rata-rata kemampuan siswa dalam menganalisis teks negosiasi sebelum menggunakan fish bowl technique adalah 6I,79 dan standar deviasi adalah I4,24 serta standar error sebesar 2,44. Kemampuan tersebut belum mencapai KKM yang ditentukan oleh sekolah, yaitu sebesar 75. Dalam hal ini, kemampuan siswa menganalisis teks negosiasi sebelum menggunakan fish bowl technique berada pada kategori cukup jika dikaitkan dengan rentang nilai. Perolehan data dari lapangan dapat dideskripsikan pada Tabel 2.

Tabel 2

Identifikasi Kecenderungan Hasil Menganalisis Teks Negosiasi sebelum Menerapkan Fish Bowl Technique

\begin{tabular}{cccc}
\hline Rentang & F. Absolute & F.Relatif & Kategori \\
\hline $85-100$ & 0 & $0 \%$ & Sangat Baik \\
$70-84$ & 18 & $51 \%$ & Baik \\
$60-69$ & 2 & $6 \%$ & Cukup \\
$50-59$ & 15 & $43 \%$ & Kurang \\
$0-49$ & 0 & 0 & Sangat Kurang \\
\hline
\end{tabular}

Berdasarkan Tabel 2, dapat diketahui bahwa kemampuan menganalisis teks negosiasi sebelum menerapkan fish bowl technique terbagi atas: kategori sangat baik 0 (0\%). kategori baik sebesar 5I\% sebanyak 18 orang siswa, kategori cukup sebesar 6\% sebanyak 2 orang siswa, kategori kurang sebesar $43 \%$ sebanyak 15 orang siswa, dan kategori sangat kurang $0(0 \%)$.

\section{Kemampuan Menganalisis Teks Negosiasi setelah Menerapkan Fish Bowl Technique (Post-Test)}

Berdasarkan nilai hasil belajar dalam menganalisis teks negosias setelah menggunakan fish bowl technique diperoleh penyebaran nilai sebesar 43,7 sampai dengan I00. Maka, nilai tertinggi yang diperoleh siswa sebesar I00 dan nilai terendah yang diperoleh adalah 43,7.

Selanjutnya, dilakukan perhitungan analisis data, diperoleh nilai rata-rata kemampuan siswa dalam menganalisis teks negosiasi setelah menggunakan fish bowl technique adalah 8I,72 dan standar deviasi adalah 17,34 serta standar error sebesar 2,97. Kemampuan tersebut telah melampaui KKM yang ditentukan oleh sekolah, yaitu sebesar 75. Dalam hal ini, kemampuan siswa dalam menganalisis teks negosiasi setelah menggunakan fish bowl technique berada pada kategori sangat baik jika dikaitkan dengan rentang nilai. Perolehan data dari lapangan dapat dideskripsikan dalam Tabel 3.

Tabel 3

Identifikasi Kecenderungan Hasil Kemampuan Menganalisis Teks Negosiasi setelah Menerapkan Fish Bowl Technique

\begin{tabular}{cccc}
\hline Rentang & F. Absolute & F.Relatif & Kategori \\
\hline $85-100$ & I3 & $37 \%$ & Sangat Baik \\
$70-84$ & I7 & $49 \%$ & Baik \\
$60-69$ & 0 & $0 \%$ & Cukup \\
$50-59$ & 5 & $14 \%$ & Kurang \\
$0-49$ & 0 & $0 \%$ & Sangat Kurang \\
\end{tabular}


Berdasarkan Tabel 3, dapat diketahui bahwa kemampuan menganalisis teks negosiasi siswa sesudah menerapkan fish bowl technique terbagi atas: kategori sangat baik sebesar 37\% sebanyak I3 orang siswa, kategori baik sebesar 49\% sebanyak 17 orang siswa, kategori cukup 0\%, kategori kurang I4\% sebanyak 5 orang siswa dan kategori sangat kurang $0 \%$.

\section{Uji Persyaratan Analisis}

Untuk mengetahui lebih lanjut apakah fish bowl technique berpengaruh terhadap kemampuan menganalisis teks negosiasi, maka dilakukan uji persyaratan analisis (normalitas dan homogenitas) dan uji hipotesis.

\section{a. Uji Normalitas}

Untuk menguji normalitas data digunakan uji normalitas liliefors. Pada data kemampuan siswa menganalisis teks negosiasi sebelum menggunakan fish bowl technique diperoleh data Lhitung $=0,14357$. Setelah Lhitung diketahui, selanjutnya dikonsultasikan melalui uji liliefors pada taraf signifikasi $\alpha=0,05$ dan $\mathrm{n}=35$, diperoleh $\mathrm{L}_{\text {tabel }}=0,149$. Dengan demikian, dapat disimpulkan bahwa Lhitung $<\mathrm{L}_{\text {tabel }}$ yaitu $0, \mathrm{I} 4357<0,149$. Oleh karena itu, data kemampuan menganalisis teks negosiasi sebelum menggunakan fish bowl technique berdistribusi normal.

Selanjutnya, pada data kemampuan siswa menganalisis teks negosiasi sesudah menggunakan fish bowl technique diperoleh data Lhitung $=0$, I4602. Setelah Lhitung diketahui, selanjutnya dikonsultasikan melalui uji liliefors pada taraf signifikasi $\alpha=0,05$ dan $\mathrm{n}=35$, diperoleh $\mathrm{L}_{\mathrm{tabel}}=0, \mathrm{I} 49$. Dengan demikian, dapat disimpulkan bahwa Lhitung < Ltabel, yaitu 0,I4602<0,I49. Oleh karena itu, data kemampuan menganalisis teks negosiasi setelah menerapkan fish bowl technique berdistribusi normal. Berikut merupakan data uji normalitas kemampuan siswa dalam menganalisis teks negosiasi dengan menggunakan model fish bowl technique dan konvensional sebagaimana Tabel 4.

Tabel 4

Data Hasil Uji Normalitas

\begin{tabular}{ccccc}
\hline No & & Lhitung & Ltabel & Keterangan \\
\hline I & Post-Test & $0, I 4357$ & $0, I 49$ & Normal \\
2 & Post-Test & 0,14602 & $0, I 49$ & Normal \\
\hline
\end{tabular}

\section{b. Uji Homogenitas}

Untuk melakukan pengujian homogenitas data dilakukan uji homogenitas dua varians, yaitu varians terbesar dan varians terkecil. $F$ untuk $\alpha=0,05$ diperoleh $F_{\text {tabel }}=4$,I3925. Jadi $F_{\text {hitung }}<F_{\text {tabel }}$ yakni $0,67338<4,13925$ serta dapat disimpulkan bahwa sampel penelitian berasal dari populasi yang homogen.

\section{c. Uji Hipotesis}

Setelah pengujian normalitas dan homogenitas dilakukan, maka diketahui bahwa data sebelum dan sesudah perlakuan adalah berdistribusi normal dan mempunyai varians yang sama (homogen). Dengan demikian, pengujian hipotesis dilakukan dengan menggunakan uji statistik t (uji beda). Berdasarkan perhitungan di atas, diperoleh nilai thitung $=5,19$. Setelah thitung diketahui, selanjutnya nilai tersebut dikonsultasikan pada taraf signifikansi $\alpha=0,05$ dan $\mathrm{n}=35$, diperoleh tabel $=4,13925$. Dengan demikian, dapat disimpulkan bahwa thitung $>$ tabel yaitu 5,19>4,13925, sehingga hipotesis nihil $\left(\mathrm{H}_{0}\right)$ ditolak dan hipotesis alternatif $\left(\mathrm{H}_{\mathrm{a}}\right)$ diterima.

\section{Pengaruh Fish Bowl Technique terhadap Kemampuan Menganalisis Teks Negosiasi Siswa Kelas X SMA Negeri I Tanjungbalai}

Hasil pengujian hipotesis menunjukkan bahwa secara umum fish bowl technique memberikan pengaruh yang signifikan terhadap kemampuan menganalisis siswa. Dari hasil uji hipotesis yang dilakukan 
menunjukkan bahwa varians yang sama (homogen). Untuk taraf taraf signifikansi dengan $\alpha=0,05$ dan $n$ 35. diperoleh $t_{\text {tabel }}=4,13925$. Dengan demikian, dapat disimpulkan bahwa thitung $>$ tabel yaitu 5,I9>4,I3925, sehingga hipotesis nihil $\left(\mathrm{H}_{0}\right)$ ditolak dan hipotesis alternatif $\left(\mathrm{H}_{\mathrm{a}}\right)$ diterima. Hal ini berarti bahwa penerapan fish bowl techniqe terhdap siswa kelas X SMA Negeri I Tanjungbalai memiliki peningkatan pada proses pembelajaran dari pada pembelajaran sebelum menerapkan fish bowl technique. Pada hasil post-test memiliki peningkatan nlai karena diberikan perlakuan teknik pembelajaran fish bowl technique dengan langkah-langkah yang telah ditentukan. Sudjana, (2010) menjelaskan bahwa (I) pendidik bersama siswa memilih dan menentukan materi yang akan di evaluasi sebagai bahan diskusi kelompok lingkaran dalam. Misalnya, evaluasi tentang, program pelatihan pengelolaan pembelajaran yang diselanggarakan oleh suatu lembaga. Diskusi akan dilakukan untuk menilai komponen-komponen program seperti tujuan, kurikulum (mata pelajaran, metode dan teknik pembelajaran, dan evaluasi), fasilitas dan alat-alat, jadwal kegiatan, akomodasi dan lain sebagainya. Kemudian disusun pertanyaan untuk masing-masing komponen itu, misalnya apakah yang telah dianggap baik dan apakah yang masih perlu dikembangkan dalam setiap komponen. Pertanyaan- pertanyaan itu dapat pula ditujukan untuk keseluruhan program. (2) Pendidik menugasi siswa untuk menyiapkan susunan tempat duduk yang terdiri atas lingkaran dalam dan lingkaran luar. (3) Setelah para siswa menempati tempat duduk pada kelompok masing-masing, pendidik memberi petunjuk, tentang cara melakukan diskusi oleh mereka yang berada di lingkaran dalam dan cara mengamati yang dilakukan oleh mereka yang berada di lingkaran luar. Perlu pula ditunjuk seorang siswa sebagai pencatat isi pembicaraan dalam diskusi itu. (4) Para siswa yang berada di lingkaran dalam berdiskusi untuk menjawab pertanyaan-pertanyaan itu. Diskusi itu dimulai oleh pimpinan diskusi dengan pertanyaan awal sesuai dengan butir I di atas dan kemudian dijawab dan ditanggapi oleh siswa lainnya. Pengawas mendengarkan diskusi dan sewaktu-waktu mencatat hal-hal yang didiskusikan. Pencatat menyusun pokok-pokok hasil pembicaraan dalam diskusi. (5) Siswa yang duduk di lingkaran luar dapat mengajukan jawaban atau pendapatnya dengan menukar tempat duduk, sehingga yang bersangkutan dapat berada di tempat duduk yang berada di lingkaran dalam. Ketika seseorang siswa dari lingkaran luar ingin menyampaikan pendapat, maka ia dapat menyentuh seorang temannya yang duduk di lingkaran dalam dan kemudian bertukar tempat. (6) Selesai diskusi, pendidik bersama siswa mengevaluasi isi, proses dan hasil penggunaan teknik ini. Dalam mengevaluasi isi pembicaraan, pokok pembicaraan yang ditulis oleh pencatat menjadi salah satu masukan penting.

Pada prinsipnya, fish bowl technique memberikan pengaruh terhadap kemampuan menganlisis siswa kelas X SMA Negeri I Tanjungbalai. Hal ini disebabkan oleh adanya keunggulan-keunggulan yang dimiliki oleh fish bowl technique. Teknik ini mampu menunjukkan keunggulannya selama proses pembelajaran dilakukan. Ditambah dengan pendayagunaan media audio visul yang digunakan, sehingga mampu merangsang minat dan motivasi belajar siswa karena membuat pembelajaran siswa tidak monoton. Tes dilakukan sebanyak 2 kali yaitu sebelum menerapkan teknik pembelajaran (pre-test) dan setelah menerapkan teknik pembelajaran (post-test) sesuai dengan jadwal pelaksanaan tes. Bentuk tes yang dilakukan berupa memberi soal teks esay dengan teks yang berbeda saat pengambilan data pre-test dan post-test. Tes ini bertujuan untuk melihat perbedaan dan pengaruh teknik pembelajaran fish bowl technique terhadap kemampuan menganalisis siswa. Sebelum tes dilaksanakan, sudah dapat diprediksi bahwa terdapat perbedaan hasil belajar siswa sebelum menerapkan fish bowl technique (pre-test) dan setelah menerapkan fish bowl technique (post-test). Sudjana, (2010) mengatakan bahwa fish bowl adalah kegiatan pembelajaran dalam bentuk diskusi yang diamati, dimana kegiatan pembelajaran dilakukan dalam kelompok yang jumlahnya tidak terlalu besar. Siswa dibagi menjadi dua kelompok yang terdiri atas kelompok lingkaran dalam dan kelompok lingkaran luar. Diantara keunggulan teknik pembelajaran fish bowl technique yaitu: (I) mendorong siswa berpikir kritis, (2) mendorong siswa menyumbangkan buah pikirannya untuk memecahkan masalah bersama, (3) meningkatkan aktivitas belajar siswa dalam proses pembelajaran. Berdasarkan pendapat tersebut, dapat dipahami bahwa fish bowl technique dapat memperbaiki dan meningkatkan aktivitas belajar siswa, karena dengan teknik ini siswa lebih berani dalam menyumbangkan pikiranya, dapat menyelesaikan masalah dengan baik, dan siswa lebih berpikir dengan 
kritis. Diskusi kelompok kelas dapat memberikan sumbangan yang berharga terhadap belajar siswa antara lain: (I) membantu siswa untuk tiba kepada pengambilan keputusan sendiri yang lebih baik, (2) siswa tidak mudah terjebak oleh pemikiran sendiri yang kadang-kadang salah dan penuh prasangka, (3) diskusi kelas memberi motivasi terhadap berpikir dan meningkatkan perhatian kelas terhadap apa yang sedang mereja pelajari, (4) diskusi juga membantu mengerahkan atau mendekatkan hubungan antara kegiatan kelas dengan tingkat perhatian dan derajat pengertian dari seluruh anggota kelas, dan (4) untuk mencari suatu keputusan akhir dari sebuah masalah.

Pada proses pembelajaran dengan menggunakan teknik fish bowl technique memiliki salah satu kelebihan yakni dapat merangsang semangat siswa dalam menganalisis teks negosiasi, hal ini disebabkan karena setiap siswa (individu atau kelompok) diberikan kesempatan yang sama untuk mempertangungjawabkan secara mandiri serta menjelaskan materi kepada teman yang lainnya. Pada proses pembelajaran dengan menggunakan metode biasa tanpa menggunakan fish bowl technique tidak memacu semangat siswa untuk berperan aktif dalam menyampaikan gagasan mereka mengenai materi yang dipelajari, sehingga tidak ada suasana yang aktif dalam pembelajaran dan menjadikan hasil belajar siswa tidak sesuai dengan yang diharapkan. Oleh sebab itu, siswa yang merasa kesulitan dalam pembelajaran menganalisis teks negosiasi tidak tertarik melakukan kegiatan menganalisis teks.

Merujuk pada hasil penelitian yang telah dijabarkan, perolehan skor siswa menganalisis teks negosiasi setelah menggunakan fish bowl technique (post-test) lebih unggul dibandingkan dengan skor siswa menganalisis teks negosiasi sebelum menggunakan fish bowl technique (pre-test). Hal tersebut dapat dilihat dari hasil nilai rata-rata nilai yang diperoleh. Nilai rata-rata pre-test sebesar 61,79, sedangkan nilai rata-rata post-test diperoleh sebesar 8I,72. Hasil ini memiliki kesamaan dengan beberapa penelitian yang peningkatan hasil post-test dengan menggunakan fish bowl technique. Hasil penelitian pertama yang dijabarkan oleh Azwar dan Syahputri (2018), menunjukkan bahwa nilai rata-rata pre-tes 59,56 dengan standar deviasi $\mathrm{I} 4,00$, sedangkan nilai rata-rata post-tes 74,56 dengan standar deviasi $\mathrm{I} 2,40$ berdasarkan uraian di atas terdapat peningkatan antara nilai rata-rata pre-tes dengan nilai rata-rata post-tes dari 59,56 menjadi 74,56, sehingga mencapai nilai Kriteria Ketuntasan Minimal (KKM) yaitu 75. Sejalan dengan hal tersebut penelitian yang dilakukan Istiningsih, Widari, \& Hasanah, (2018) bahwa fish bowl technique berpengaruh terhadap hasil belajar yang ditunjukkan pada siklus I dengan perolehan nilai rata-rata 75,375, nilai ketuntasan klasikal 70,83\% dan skor rata-rata aktivitas siswa 53 dengan kategori cukup aktif. Pada siklus II data hasil belajar dan aktivitas siswa mengalami peningkatan yakni rata-rata 82,79I dengan ketuntasan klasikal 87,5\% dan skor rata-rata aktivitas belajar siswa 58,5 dengan kriteria aktif.

Memperkuat hasil penelitian ini, peneliti membandingkan hasil penelitian yang diperoleh dengan beberapa penelitian terdahulu yang relevan dengan penelitian ini. Berikut disajikan hasil penelitian terlebih dahulu yang relevan dengan penelitian ini. Adapun penelitian yang relevan terhadap penelitian ini adalah hasil penelitian yang dilakukan oleh Rahmadan (20I4) yang menunjukkan nilai rata-rata kelas eksperimen adalah 78,06, sedangkan untuk kelas kontrol adalah 65. Dengan demikian, dapat dikatakan bahwa nilai rata-rata kemampuan menulis pada kelas eksperimen lebih tinggi daripada kelas kontrol. Ini terbukti dari hasil uji " $\mathrm{t}$ " diperoleh thitung $>$ tabel yaitu 7,86>2,03. Sejalan dengan itu, dalam penelitian (Fitri, 2015) didapat rata-rata hasil belajar kelas eksperimen lebih baik dari pada hasil belajar kelas kontrol, dengan demikian dapat disimpulkan bahwa hasil belajar matematika siswa yang diajar menggunakan pembelajaran teknik cawan ikan lebih baik dari hasil belajar matematika siswa yang pembelajarannya menggunakan pembelajaran konvensional.

Penelitian lain yang juga menunjukkan hasil peningkatan dengan penggunaan fish bowl technique adalah penelitian yang dilakukan oleh Athirah, Garancang, Suhardiman (2018) dengan hasil penelitian menunjukkan bahwa implementasi fish bowl technique lebih efektif untuk meningkatkan kemampuan berbahasa dan pemahaman konsep pada kelas XI MIPA 2 dibandingkan dengan diskusi kelas pada kelas XI MIPA I MAN I Makassar. Penelitian yang dilakukan oleh Yunita \& Mujiburrahman (2018) juga menunjukkan penggunaan metode pembelajaran fish bowl sebelum dan sesudah, didapatkan hasil uji thitung menunjukkan nilai thitung sebesar 7.342 maka berdasarkan taraf signifikansi $5 \%$ dan d.b $=23$ ternyata 
besarnya angka batas penolakan hipotesis nol (Ho) yang dinyatakan dalam tabel distribusi $t$ adalah 2,069. Kenyataan ini menunjukkan bahwa nilai thitung lebih besar dari pada nilai tabel $(7.342>2.069)$, Karena thitung lebih besar dari tabel, berarti hipotesis nihil ( $\mathrm{Ho}$ ) ditolak dan hipotesis alternatif (Ha) diterima, maka dapat ditarik kesimpulan bahwa ada pengaruh metode pembelajaran fish bowl terhadap hasil belajar siswa.

Jadi, dari penjelasan di atas dan didukung oleh hasil penelitian-penelitian terdahulu dan memiliki relevansi dengan penelitian ini, dapat disimpulkan bahwa kemampuan siswa dalam menganalisis teks negosiasi dengan menggunakan fish bowl technique teruji dapat meningkatkan kemampuan menganalisis teks negosiasi siswa kelas X SMA Negeri I Tanjungbalai tahun pembelajaran 2019/2020. Hal ini membuktikan bahwa fish bowl technique berpengaruh dalam meningkatkan kemampuan menganalisis teks negosiasi sesuai dengan isi struktur dan kebahasaan teks negosiasi.

\section{SIMPULAN}

Berdasarkan penelitian yang telah dilakukan, dapat disimpulkan bahwa Kemampuan menganalisis teks negosiasi siswa kelas X SMA Negeri I Tanjungbalai tahun pembelajaran 2019/2020 sebelum menerapkan fish bowl technique, termasuk dalam kategori cukup dan masih berada di bawah KKM yang telah ditentukan sekolah yaitu 76 . Hal tersebut karena nilai rata-rata menganalisis teks negosiasi siswa sebelum menerapkan fish bowl technique adalah 6I,79 dan standar deviasi I4.24. Kemampuan menganalisis teks negosiasi siswa kelas X SMA Negeri I Tanjungbalai tahun pembelajaran 2019/2020 setelah menerapkan fish bowl technique termasuk ke dalam kategori baik dan sudah mencapai KKM. Hal tersebut karena nilai rata-rata siswa setelah menerapkan fish bowl technique adalah 8I,72 dengan standar deviasi 17,34. Penerapan fish bowl technique berpengaruh positif terhadap kemampuan menganalisis teks negosiasi siswa kelas X SMA Negeri I Tanjungbalai tahun pembelajaran 2019/2020. Pengaruh positif itu ditunjukkan oleh adanya peningkatan nilai yang diperoleh siswa sebelum menerapkan fish bowl technique (pre-test) dan setelah menerapkan fish bowl technique (post-test). Dengan adanya perlakuan teknik pembelajaran fish bowl technique ini lebih mempermudah siswa lebih aktif dalam proses pembelajaran dengan menuangkan ide-ide kreatif dalam proses diskusi dan membuat siswa lebih termotivasi untuk mengikuti proses pembelajaran. Dengan demikian, fish bowl technique berpengaruh signifikan untuk meningkatkan kemampuan menganalisis teks negosiasi siswa kelas X SMA Negeri I Tanjungbalai tahun pembelajaran 2019/2020. Hal ini dapat dilihat dengan adanya meningkatnya dari hasil pre-test dengan hasil post-test.

Berdasarkan hasil yang diperoleh dari studi ini, penerapan fish bowl technique di sekolah-sekolah yang terdapat di Indonesia sangat direkomendasikan. Penyebarluasan informasi yang berkaitan dengan manfaat fish bowl technique perlu dilakukan agar dapat menjadi salah satu referensi model pembelajaran yang dapat digunakan guru untuk menciptakan variasi dalam pembelajaran dan meningkatkan kemampuan serta hasil belajar siswa. Selain itu, perlu dilakukan penelitian lebih lanjut mengenai fish bowl technique ini untuk mengetahui kelebihan dan kekurangannya saat diterapkan dalam materi atau pembelajaran yang berbeda serta dapat mengetahui manfaat-manfaat yang diperoleh saat menerapkan model pembelajaran ini.

\section{UCAPAN TERIMA KASIH}

Penulis mengucapkan terima kasih kepada Lembaga Penelitian dan Pengabdian Kepada Masyarakat (LPPM) Universitas Negeri Medan yang telah memberikan dukungan finansial dalam penelitian ini. Penulis juga mengucapkan terima kasih kepada semua pihak yang telah berkontribusi dalam penelitian ini, kepala sekolah, guru bidang studi bahasa Indoneisa, tata usaha, serta seluruh siswa kelas X SMA Negeri I Tanjungbalai sehingga penelitian ini dapat terlaksana dengan baik.

\section{DAFTAR PUSTAKA}

Alwi, Hasan, dkk. (2007). Tata bahasa baku bahasa Indonesia. Jakarta: Pustaka. 
Athirah., Garancang, S., Suhardiman. (2018). Efektivitas fish bowl technique sebagai sarana sosial terhadap kemampuan berbahasa dan pemahaman konsep. Jurnal Pendidikan Fisika, 6(2), I02I09. http://I03.55.216.56/index.php/PendidikanFisika/article/viewFile/359I/5258

Aswadi, J., \& Akhmad, H. (2016). Fish bowl technique and learning interest effects on speaking achievement of SMK Sembawa. Jambi-English Language Teaching, I(I). I-I I. Retrieved from: https://www.online-journal.unja.ac.id/jelt/article/view/2899/8I31

Azwar, E., \& Syahputri, A. N. (2018). Pengaruh model three stage fish bowl terhadap hasil belajar siswa pada materi ekosistem di kelas X SMA swasta persiapan STABAT tahun pelajaran 2016/2017. BEST Journal (Biology Education, Sains and Technology), I(2), 20-27. doi: https:/ / doi.org/I0.30743/best.vIi2.789

Dewi, P. N. S., Suandi, I. N., \& Yasa, I. N. (2015). Implementasi pembelajaran menulis teks negosiasi berdasarkan kurikulum 2013 di kelas Xb akuntansi SMK Negeri I Singaraja. Jurnal Pendidikan Bahasa dan Sastra Indonesia Undiksha, 3(I). I-I2. doi: http://dx.doi.org/I0.23887/jipbs.v3iI.5058

Effendi, A. (2018). The effectiveness of fish bowl technique towards students'self efficacy in speaking. JOLLT Journal of Languages and Language Teaching, 5(2), 46-5I. doi: https:// doi.org/I0.33394/jollt.v5i2.345

Eviyana, K., Hilal, I., \& Karomani, K. (20I3). Pembelajaran menulis teks negosiasi siswa kelas X SMA Negeri I Pringsewu. Jurnal Kata (Bahasa, Sastra, dan Pembelajarannya), I(I). I-9. Retrieved from: http://jurnal.fkip.unila.ac.id/index.php/BINDOI/article/view/5057/3I75

Fitri, V. R. \& Niniwati. (2015). Pengaruh Teknik cawan ikan dalam proses pembelajaran matematika terhadap hasil belajar siswa kelas X SMA Negeri 2 Bayang. Jumal Fakultas Keguruan dan Ilmu Pendidikan, 3(I) I-I0. Retrieved from: file:///C:/Users/Lenovo/Downloads/3I83File\%20Utama\%20Naskah-II383-I-I0-20I403I5.pdf

Francisko,. R. (2015) Pengaruh model pembelajaran inkuiri terhadap kemampuan memahami teks negosiasi siswa kelas X SMA Negeri 4 Medan" (Doctoral disertation UNIMED) Diakses dari http://digilib.unimed.ac.id/I5486/

Fristanti, A. A. F., Sudarmaji, S., \& Saputro, E. (2019). Kemampuan menganalisis teks negosiasi siswa kelas X semester ganjil SMK PGRI 2 Bandar Lampung tahun pelajaran 20I9/2020. Warahan: Jurnal Ilmiah Mahasiswa Pendidikan Bahasa dan Sastra Indonesia, I(2), I-I4. Retrieved from: http://eskripsi.stkippgribl.ac.id/index.php/warahan/article/view/209/70

Huda, A. I. N., Turahmat, T., \& Azizah, A. (2018). Peningkatan kemampuan menulis teks negosiasi dengan model pembelajaran group investigation pada siswa kelas X SMA Negeri 2 Rembang. Jurnal Pendidikan Bahasa Indonesia, 5(2), 19-38. Retrieved from: file://C:/Users/Lenovo/Downloads/2349-5I25-I-SM\%20(I).pdf

Isodarus, P. B. (20I7). Pembelajaran bahasa Indonesia berbasis teks. Sintesis, II(I), I-I I. Retrieved from: https://www.e-journal.usd.ac.id/index.php/sintesis/article/view/927/73I

Istiningsih, S., Widari, N. K. S., \& Hasanah, N. (2018). Efektivitas teknik mangkuk ikan atau akuarium (fish bowl) untuk meningkatkan hasil belajar IPS pada siswa kelas Va SDN I6 Cakranegara tahun pelajaran 2016/2017. Jurnal Kesejahteraan Keluarga dan Pendidikan, 5(I), 82-94. Retrieved from: http://journal.unj.ac.id/unj/index.php/jkkp/article/view/6409/4887

Kemendikbud. (20I4) Bahasa Indonesia SMA/MA/SMK/MK Kelas X. Jakarta: Kementerian Pendidikan dan Kebudayaan.

Kosasih, E. 20I4. Jenis-Jenis Teks. Bandung: Yrama Widya.

Mahsun. (20I4). Teks dalam pembelajaran bahasa Indonesia kurikulum 2013. Jakarta: Rajawali Press.

Palupi, F. H. (2020). Efektivitas model connecting, organizing, reflecting, and extending (core) dalam pembelajaran menganalisis dan mengonstruksikan teks negosiasi. Jurnal METAEDUKASI, 2(I), 
23-27.

Retrieved

from:

http://jurnal.unsil.ac.id/index.php/metaedukasi/article/view/pal2I/II92

Patonah, S., Syahrullah, A., Firmansyah, D., \& San Fauziya, D. (2018). Pengaruh model pembelajaran berbasis masalah (problem based learning) pada pembelajaran menulis teks negosiasi di kelas X SMK Lentera Bangsa. Parole (Jurnal Pendidikan Bahasa dan Sastra Indonesia), I(5), 807-8I4. doi: http://dx.doi.org/I0.22460/p.vIi5p\%25p.I269

Rahmadani. (20I4). Pengaruh metode pembelajaran fishbowl (toples ikan) terhadap kemampuan menulis naskah drama oleh siswa kelas VIII Yayasan Pendidikan Nurul Khair Desa Tandam Hilir Ii Tahun Pembelajaran 2013/20I4. Kode: Jurnal Bahasa, 3(3) 13-24. doi: https:// doi.org/I0.24II4/kjb.v3i3.I635

Roestiyah. (20I4). Strategi Belajar Mengajar. Jakarta: Rineka Cipta.

Sagala, S. (20I4). Konsep dan Makna Pembelajaran untuk membantu memecahkan problematika belajar dan mengajar. Bandung: Alfabeta.

Sartika. D. (2019). Pengaruh model pembelajaran koopeatif team games tournament terhadap kemampuan menganalisis struktur dan kebahasaan teks negosiasi siswa kelas X SMK Negeri 2 Medan tahun pembelajaran 2018/2019. (Doctoral disertation UNIMED). Retrieved from: http:/ / digilib.unimed.ac.id/39067/

Silvia, L. (2019). Kemampuan siswa kelas X SMA Negeri 3 Langsa menulis teks negosiasi. Jurnal Samudra Bahasa, 2(I), I-8. Retrieved from: https://www.ejurnalunsam.id/index.php/JSB/article/view/I6I0/I205

Sudjana. (2010). Metode \& teknik pembelajaran partisipatif. Bandung: Falah Production.

Sugiyono. (2016). Metode penelitian pendidikan: Pendekatan kuantitatif, kualitatif, dan R\&D. Bandung: Alfabeta.

Sunarsih, E., Adelina, S., \& Yanti, L. (2018). Pengaruh model pembelajaran problem based learning terhadap hasil belajar menulis teks negosiasi siswa kelas X SMA Negeri I Singkawang Tahun Ajaran 2017/2018. JP-BSI (Jurnal Pendidikan Bahasa dan Sastra Indonesia), 3(2), 89-93. Retrieved from: https://core.ac.uk/reader/23I282980

Tricio, J., Montt, J., Orsini, C., Gracia, B., Pampin, F., Quinteros, C., \& Fuentes, N. (2019). Student experiences of two small group learning-teaching formats: Seminar and fish bowl. European Journal of Dental Education, 23(2), I5I-I58. doi: https:// doi.org/I0.I I I / eje.I24I4

Ulina, S.D., (2016) Pengaruh model pembelajaran inkuiri (inquiri based learning) terhadap kemampuan menganalisis teks negosiai siswa kelas X SMA Negeri 2 Kabanjahe tahun pembelajaran 2015/2016. (Doctoral disertation UNIMED). Retrieved from: http://digilib.unimed.ac.id/19477/

Wahidin, W., Sukamto, S., \& Heryana, N. (2015). Pelaksanaan pembelajaran keterampilan bernegosiasi pada siswa kelas XI akomodasi perhotelan I SMK N 5. Jurnal Pendidikan dan Pembelajaran. 3(2), I-I4. Retrieved from: https://jurnal.untan.ac.id/index.php/jpdpb/article/view/I5446

Warsono dan Hariyanto. (2013). Pembelajaran aktif. Bandung: Remaja Rosdakarya.

Yunita, M., \& Mujiburrahman, M. (2018). Pengaruh metode fish bowl terhadap hasil belajar siswa pada mata pelajaran IPS terpadu kelas VIII di Mts Al-Akhyar Bagik Polak Kabupaten Lombok Barat tahun pelajaran 2015/2016. Realita: Jurnal Bimbingan dan Konseling, 2(I), 224-238. Retrieved from: https://jurnal.ikipmataram.ac.id/index.php/realita/article/view/747/70I

Zaini, H. (2010). Strategi Pembelajaran Aktif. Jakarta: Bumi Aksara.

Zumaeroh (20I0). Mengenali konflik dalam negosiasi. Majalah Ilmiah Ekonomika, I3 (4), I30 -I62. Retrieved from: https://media.neliti.com/media/publications/23I53-ID-mengenali-konflikdalam-negosiasi.pdf 